\title{
Creation of winter rapeseed Brassica napus L. commercial line of biotechnological plants, resistant to the glyphosate action
}

\author{
I. S. Hnatiuk ${ }^{1,2}$, O. I. Varchenko ${ }^{1,2}$, M. V. Kuchuk ${ }^{1}$, M. F. Parii ${ }^{2,3}$, Yu. V. Symonenko ${ }^{1,2}$ \\ ${ }^{1}$ Institute of Cell Biology and Genetic Engineering, NAS of Ukraine \\ 148, Akademika Zabolotnogo Str., Kyiv, Ukraine, 03143 \\ ${ }^{2}$ Ltd "Ukrainian Scientific Institute of Plant Breeding" (VNIS) \\ 30, Vasylkivska Str., Kyiv, Ukraine, 03022 \\ ${ }^{3}$ National University of Life and Environmental Sciences of Ukraine \\ 15, Heroiv Oborony Str., Kyiv, Ukraine, 03041 \\ ignatyuk94@gmail.com
}

\begin{abstract}
Aim. To create biotechnological plants of a commercial line winter rapeseed, which carry the glyphosate and phosphinostricin resistance genes. Methods. In vitro tissue culture method, Agrobacterium-mediated genetic transformation, polymerase chain reaction and $\chi^{2}$ methods were used. Results. The PCR analysis results are presented for the biotechnological winter rapeseed plants obtained after genetic transformation to confirm the presence of CP4 epsps gene insert in 11 of 12 plants, as well as the presence of bar gene integration in 6 of 7 plants. All obtained regenerant plants were adapted to in vivo conditions, treated with glyphosate and vernalized. The obtained seeds were sterile germinated and the segregation was determined based on the resistance to the selective agent. Conclusion. 11 biotechnological plants with the glyphosate (epsps) and kanamycin (nptII) resistance genes were obtained, as well as 6 biotechnological plants, which carry phosphinothricin (bar) resistance genes in addition to the epsps gene. The presence of the CP4 EPSPS protein in transgenic rapeseed plants has been proven by the molecular analysis of protein expression using an immunoassay system. The expression of selective agents resistance genes was confirmed in $\mathrm{T}_{1}$ generation.
\end{abstract}

Keywo rd s: Brassica napus, winter rapeseed, bar gene, epsps gene, nptII gene, genetic transformation.

\section{Introduction}

Among the oilseeds of the cabbage family, the winter rape Brassica napus L. ranks first in terms of oil content in its seeds (48-52\%), as well as $16-29 \%$ protein, $6-7 \%$ fiber, $17 \%$ carbohydrates. Rapeseed oil is consumed in its pure form; it is the best raw material for the

(C) 2020 I. S. Hnatiuk et al.; Published by the Institute of Molecular Biology and Genetics, NAS of Ukraine on behalf of Biopolymers and Cell. This is an Open Access article distributed under the terms of the Creative Commons Attribution License (http://creativecommons.org/licenses/by/4.0/), which permits unrestricted reuse, distribution, and reproduction in any medium, provided the original work is properly cited 
production of various food products and industrial processing. According to the USDA report, the leaders in rapeseed production in 2019 were: the EU - 22 million tons, Canada 21.1 million tons and China -12.85 million tons. Ukraine ranks 7 th on this list with 2.2 million tons. Winter rapeseed has a high level of profitability, its cultivation is economically profitable, and production volumes in Ukraine have increased over the past 3 years by $62 \%$ : from 0.8 million hectares to $1.3 \mathrm{mil}-$ lion hectares.

Worldwide, rapeseed crops are severely damaged by weeds, causing 30 to $45 \%$ losses. Comprehensive weed control programs using classical and chemical methods have been successfully implemented for many decades. However, with increasing production, there is a need for chemical herbicides with a broad spectrum of action and further development of crops resistant to such herbicides [1].

Today, glyphosate remains the active ingredient in most of non-systemic herbicides, such as Roundup $\AA$, Tornado $\AA$, Uragan Forte $\AA$, "Triumph", "Agrokiller", etc., which are used to control annual and perennial weeds during vegetation.

The glyphosate action is due to the fact that it inhibits the plant enzyme 5-enolpyruvylshikimate-3-phosphate synthase (EPSPS). The EPSPS enzyme catalyzes the transfer of the enolpyruvyl portion of phosphoenolpyruvate to the 5-hydroxyl group of shikimate-3-phosphate to form 5-enolpyruvylshikimate-3-phosphate at the penultimate stage of the shikimate pathway. In plants, fungi, and bacteria, the shikimate pathway is critical for the biosynthesis of aromatic amino acids such as tyrosine, tryptophan, and phenylalanine. EPSPS is a target for N-phosphonomethyl-glycine (glyphosate). Glyphosate resembles transient phosphoenolpyruvate and forms a dead-end complex with the chloroplast-bound enzyme EPSPS, resulting in complete inhibition of the shikimate pathway. Therefore, when glyphosate enters the plant, it penetrates into the cells, blocks the synthesis of a number of amino acids, and the plant dies [2].

Glyphosate-resistant varieties were created using the glyphosate-insensitive epsps gene isolated from Agrobacterium sp. strain CP4 [3, 4].

To date, the most common methods for genetic information transfer are Agrobacteriummediated and biolistic transformation. Agrobacterium-mediated genetic transformation is based on the natural ability of agrobacteria to transmit genetic information to a plant cell, and its effectiveness depends on many factors, such as: genotype of the original plant, its physiological state, regeneration potential, choice of explant for inoculation, inoculation conditions, etc. [5]. In our study, the method of choise was transformation with agrobacteria, because it allows stable integration of a specific DNA fragment into the plant genome and usually leads to fewer embedded copies or permutations and stable expression over generations than the methods of direct DNA transfer [6].

Despite the fact that the transgenic spring rape plants with glyphosate resistance genes have already been created in Ukraine [7-9], the issue of developing approaches to genetic modification of commercial lines of winter rape remains relevant today.

Thus, the aim of our work was to obtain the biotechnological plants of winter rapeseed 
B. napus L. Ukrainian breeding lines that carry glyphosate-resistance genes, and to test the $\mathrm{T} 1$ generation plants for the resistance to selective agents.

\section{Materials and Methods}

\section{Plant material and in vitro culture}

We used the Bnl line of winter rape seeds, which was kindly provided by the Ukrainian Scientific Institute of Plant Breeding.

The seeds were introduced into the in vitro culture by surface sterilization by the following method: $70 \%$ ethanol treatment $-5 \mathrm{~min}$, $1.5 \%$ sodium hypochlorite solution $-20 \mathrm{~min}$, followed by washing three times in sterile distilled water for $5 \mathrm{~min}$. After sterilization, the seeds were planted on a hormone-free nutrient medium MS [10], supplemented with $400 \mathrm{mg} / \mathrm{L}$ of the antibiotic ceftriaxone $(\mathrm{Ct})$ and kept for $24 \mathrm{~h}$ in the dark at a temperature of $24{ }^{\circ} \mathrm{C}$. Next, Petri dishes were cultured for another 5 days in a culture room under a 16-h photoperiod at a temperature of $24^{\circ} \mathrm{C}$.

\section{Callusogenesis and regeneration induction}

For callusogenesis induction and shoots regeneration, we used a modified technique [11].

As the explant for transformation, a 3-day old callus, obtained from hypocotyls segments $(0.5-1 \mathrm{~cm})$ of 6-day-old rape seedlings, on the MS nutrient medium supplemented with $1 \mathrm{mg} / \mathrm{L} 2,4-\mathrm{D}$ (MSC) was used.

Organogenesis induction in transformants was performed on the MS nutrient medium supplemented with $4 \mathrm{mg} / \mathrm{L}$ 6-benzylaminopurine (BAP), $2 \mathrm{mg} / \mathrm{L}$ 2-isopentyladenine (2-iP) and $5 \mathrm{mg} / \mathrm{L} \mathrm{AgNO}_{3}$ (MSO). To select trans- genic tissues in the nutrient medium, phosphinothricin (ppt) at a concentration of $5 \mathrm{mg} / \mathrm{L}$ or kanamycin $(\mathrm{Km})$ at a concentration of $25 \mathrm{mg} / \mathrm{L}$ was added. After 2-3 weeks of cultivation, the explants were transferred to the MS regeneration media, which contained $3 \mathrm{mg} / \mathrm{L}$ BAP and $2 \mathrm{mg} / \mathrm{L} 2-\mathrm{iP}$ (MSR). At this stage, the amount of selective agent increased to $8 \mathrm{mg} / \mathrm{L}$ ppt or $50 \mathrm{mg} / \mathrm{L} \mathrm{Km}$. The elongation of the obtained shoots was performed on the MS medium with half the content of macro- and microsalts, supplemented with $0.1 \mathrm{mg} / \mathrm{L} \mathrm{BAP}$ (MSE) and with a reduced amount of selective agent $3 \mathrm{mg} / \mathrm{L}$ ppt or $25 \mathrm{mg} / \mathrm{L} \mathrm{Km}$. The rooting of plants was performed on the hormone-free MS medium with half the content of macro- and microsalts (MSRt) and supplemented with $3 \mathrm{mg} / \mathrm{L}$ ppt or $25 \mathrm{mg} / \mathrm{L} \mathrm{Km}$. Each nutrient medium was supplemented with $400 \mathrm{mg} / \mathrm{L}$ antibiotic Ceftriaxone $(\mathrm{Ct})$.

\section{Adaptation and vernalization of plants}

Regenerated plants were planted in a peat mixture and grown in a greenhouse (16-h photoperiod, $24{ }^{\circ} \mathrm{C}$ ) for $6-8$ weeks. For vernalization, the plants were placed in a climate chamber with a temperature of $4{ }^{\circ} \mathrm{C}$ and an 8 -hour photoperiod for 8 weeks. After vernalization period, the plants were grown in a greenhouse ( $24{ }^{\circ} \mathrm{C}, 16-\mathrm{h}$ photoperiod); the bud formation was observed after 4-5 weeks. To obtain seeds, all buds were covered with polyethylene isolators and self-pollinated.

\section{Bacterial strains and constructs}

For the Agrobacterium-mediated gene transfer, the soil bacteria Agrobacterium tumefaciens strain GV3101 was used, which contained one of two genetic constructs: pCB133 or pCB135. 
The pCB133 construct contains the epsps glyphosate tolerance target gene, as well as the selective phosphinothricin-acetyltransferase (bar) gene, which confers plant cells resistance to Basta ${ }^{\circledR}$ herbicide (active substance is L-phosphinothricin). The product of bar gene activity is phosphinotricin-acetyltransferase, an enzyme that neutralizes phosphinotricin which can provide the transgenic plants growth and rooting on the selective medium. The $\mathrm{pCB} 135$ construct, in addition to the epsps target gene, contains the neomycin phosphotransferase (nptII) selective gene, which provides the transgenic plant tissues resistance to the neomycin and kanamycin antibiotics (Fig. 1).

\section{Genetic transformation}

The Agrobacterium-mediated genetic transformation conditions for $B n 1$ commercial line of winter rape were previously optimized and described in [12].
A. tumefaciens GV3101 suspension was grown overnight at a $28^{\circ} \mathrm{C}$ temperature in LB media [13], which contained following antibiotics: rifampicin (Rf) $-50 \mathrm{mg} / \mathrm{L}$, ampicillin (Amp) - $100 \mathrm{mg} / \mathrm{L}$, gentamicin $(\mathrm{Gm})$ $25 \mathrm{mg} / \mathrm{L}$. Bacterial cells were centrifuged and resuspended in inoculation medium so that the optical density of the bacteria was 0.5 at a $600 \mathrm{~nm}$ light wavelength. Inoculation of precultured hypocotyls was performed for $10 \mathrm{~min}$, followed by drying on sterile filter paper. Next, the explants were placed on MSC medium and co-cultured in the dark at $24^{\circ} \mathrm{C}$. After 48 hours, they were transferred to MSC medium supplemented with $400 \mathrm{mg} / \mathrm{L} \mathrm{Ct}$ to eliminate bacterial cells and cultured for another 10-12 days.

\section{Total DNA extraction}

The total DNA was extracted by the CTAB method [14] from leaf material of regenerated rapeseed plants, B. napus L., obtained after

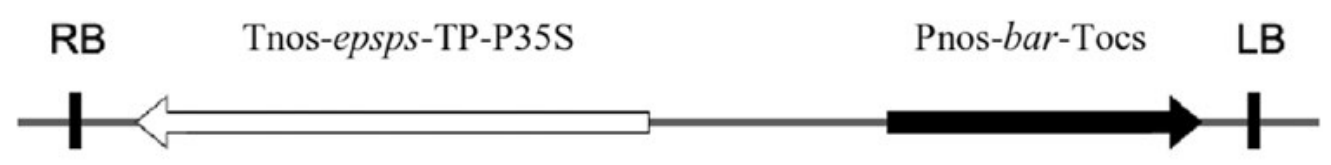

\section{pCB133}

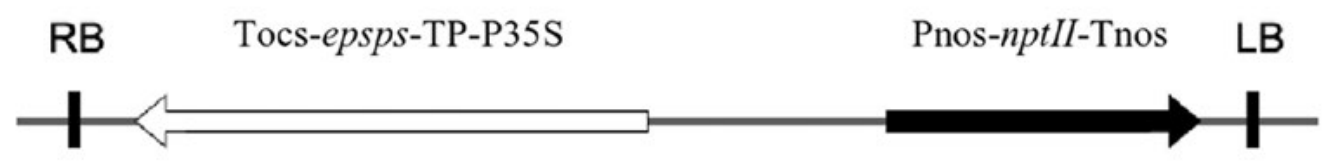

\section{pCB135}

Fig. 1. Schematic representation of the $\mathrm{pCB} 133$ and $\mathrm{pCB} 135$ vectors. $\mathrm{RB}, \mathrm{LB}-\mathrm{T}-\mathrm{DNA}$ boundaries, Tnos - nopaline synthase gene terminator, Pnos - nopaline synthase gene promoter, P35S - cauliflower mosaic virus gene promoter, Tocs - octopin synthase gene terminator, TP - transit peptide, epsps - 5-enolpyruvylshikimate-3-phosphate synthase gene, bar - phosphinothricin acetyltransferase gene of Streptomyces hygroscopicus, nptII-neomycin phosphotransferase gene of Escherichia coli. 
in vitro transformation using $A$. tumefaciens pCB133 and pCB135 genetic constructs.

\section{Polymerase chain reaction}

The reaction mixture for the CP4 epsps gene detection included: specific primers (Table 1), $2 \mu \mathrm{l}$ of PCR 10xDreamTaq ${ }^{\mathrm{TM}}$ GreenBuffer (Thermo Scientific), $0.2 \mathrm{mM}$ of each deoxyribonucleoside triphosphate (Thermo Scientific), 2 units of DreamTaq ${ }^{\mathrm{TM}}$ DNA Polymerase (Thermo Scientific), 100 ng of total DNA. The reaction mixture was brought to a final volume of $20 \mu \mathrm{l}$ with deionized Milli-Q water. The reactions were performed using the following profiles: initial denaturation for $5 \mathrm{~min}$ at $95^{\circ} \mathrm{C}, 40$ cycles denaturation for $40 \mathrm{~s}$ at $95^{\circ} \mathrm{C}$, annealing of primers for $40 \mathrm{~s}$ at $55^{\circ} \mathrm{C}$, elongation for $45 \mathrm{~s}$ at $72^{\circ} \mathrm{C}$, final elongation for $7 \mathrm{~min}$ at $72{ }^{\circ} \mathrm{C}$.

The reaction mixture for the bar gene detection included: specific primers (Table 1), $2 \mu \mathrm{l}$ of PCR 10xDreamTaq ${ }^{\mathrm{TM}}$ GreenBuffer (Thermo Scientific), $0.2 \mathrm{mM}$ of each deoxyribonucleoside triphosphate (Thermo Scientific), 2 units of DreamTaq ${ }^{\mathrm{TM}}$ DNA Polymerase (Thermo Scientific), $100 \mathrm{ng}$ of total DNA. The reaction mixture was brought to a final volume of $20 \mu \mathrm{l}$ with deionized Milli-Q water. The reactions were performed using the following profiles: initial denaturation for $5 \mathrm{~min}$ at $95^{\circ} \mathrm{C}, 40 \mathrm{cy}$ cles - denaturation for $30 \mathrm{~s}$ at $95^{\circ} \mathrm{C}$, annealing of primers for $30 \mathrm{~s}$ at $60^{\circ} \mathrm{C}$, elongation for $30 \mathrm{~s}$ at $72{ }^{\circ} \mathrm{C}$, final elongation for $7 \mathrm{~min}$ at $72{ }^{\circ} \mathrm{C}$.
Analysis of the CP4 epsps gene expression in transgenic rapeseed plants

Molecular analysis of protein expression using the Immunostrip Dipstick assay (QuickStix ${ }^{\mathrm{TM}}$ Kit) was used to detect CP4 EPSPS protein in transgenic rapeseed plants. The presence of CP4 EPSPS protein was identified by EnviroLogixR test strips coated with IgG monoclonal antibodies. To obtain samples of extracted proteins, the plant material was ground in a mortar with distilled water in a ratio of 1:5. $250 \mu \mathrm{l}$ of the sample were added to a test tube and immersed with a test strip coated with antibodies for $10 \mathrm{~min}$ at room temperature.

\section{Genetic analysis}

Rape seeds obtained by self-pollination of transgenic plants were sterile germinated on a MS hormone-free medium in a thermal room at $24{ }^{\circ} \mathrm{C}$ initially without the addition of a selective agent. Tops of 5-7-day-old seedlings with false leaves were separated and transferred to a selective medium supplemented with $8 \mathrm{mg} / \mathrm{L}$ ppt or $50 \mathrm{mg} / \mathrm{L} \mathrm{Km}$.

\section{Statistical data processing}

To estimate the coincidence probability of actually obtained genetic segregation values with theoretically expected, the Chi-squared test for goodness of fit $\left(\chi^{2}\right)$ was used.

Table 1. Specific primers used in the study

\begin{tabular}{l|l|l|l}
\hline \multicolumn{1}{c|}{ Gene } & \multicolumn{1}{|c|}{ Forward primer } & \multicolumn{1}{c}{ Reverse primer } & $\begin{array}{c}\text { The expected } \\
\text { fragment length, } b p\end{array}$ \\
\hline CP4 epsps & 5'-CAG AAC TCG CCG TGA AGA CT-3' & 5'-GAA TCC GAG GAG GTT TCC C-3' & 197 \\
\hline bar & 5'-CAG AAA CCC ACG TCA TGC CA-3' & 5'-GAG GCA CAG GGC TTC AAG AG-3' & 149 \\
\hline
\end{tabular}



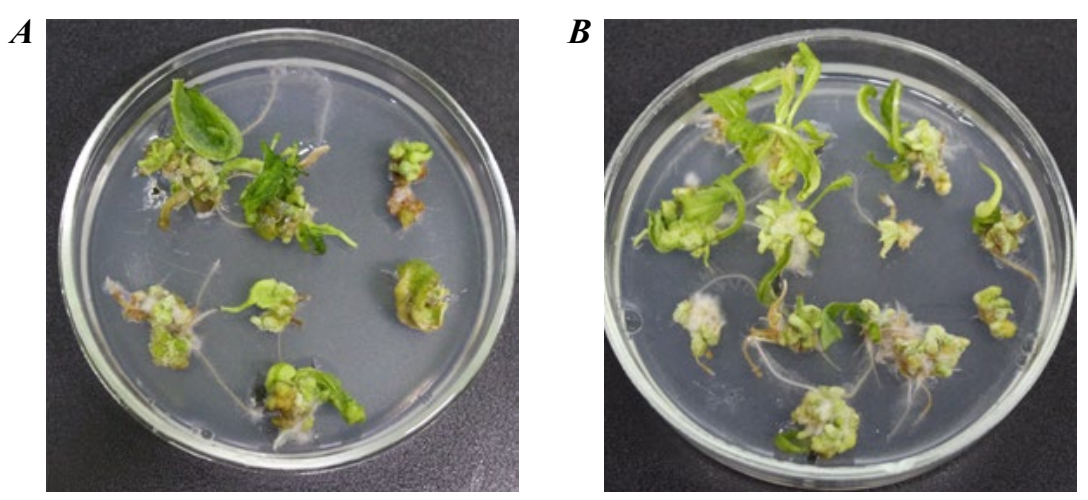

Fig. 2. Explants of winter rapeseed $B n 1$ line on the 4th week of cultivation on MSR nutrient medium, supplemented with $50 \mathrm{mg} / \mathrm{L} \mathrm{Km}$ (A) or $8 \mathrm{mg} / \mathrm{L} \mathrm{ppt} \mathrm{(B):} A$ - after transformation with the genetic construct pCB135, $B$ - after transformation with the genetic construct $\mathrm{pCB} 133$.

\section{Results and Discussions}

Six experiments were performed on the genetic transformation of the $B n l$ line of winter rapeseed with $A$. tumefaciens GV3101, which carried genetic constructs pCB133 or pCB135.

In previous studies on the genetic transformation of commercial rapeseed hypocotyls, the authors used step selection with increasing the ppt concentration in the regeneration medium to $8 \mathrm{mg} / \mathrm{L}[15,16]$. Also in some studies, the $\mathrm{Km}$ concentration was increased to $200 \mathrm{mg} / \mathrm{L}$ [17]. In our study, step selection with increasing selective agent concentration in the MSR nutrient medium made it possible to select the maximum number of transgenic plants and to reject false-positive variants (Fig. 2). For roots formation, the ppt/Km concentration was reduced to $3 \mathrm{mg} / \mathrm{L}$ or $25 \mathrm{mg} / \mathrm{L}$ in elongation (MSE) and rooting media (MSRt) respectively.

After rooting on the MSRt medium all obtained regenerated winter rape plants were planted in a peat mixture and adapted to the greenhouse conditions. Four weeks later, the

\section{$\begin{array}{lllllllllllllll}1 & 2 & 3 & 4 & 5 & 6 & 7 & \mathrm{M} & 8 & 9 & 10 & 11 & 12 & \mathrm{~K}_{1} & \mathrm{~K}_{2}\end{array}$}

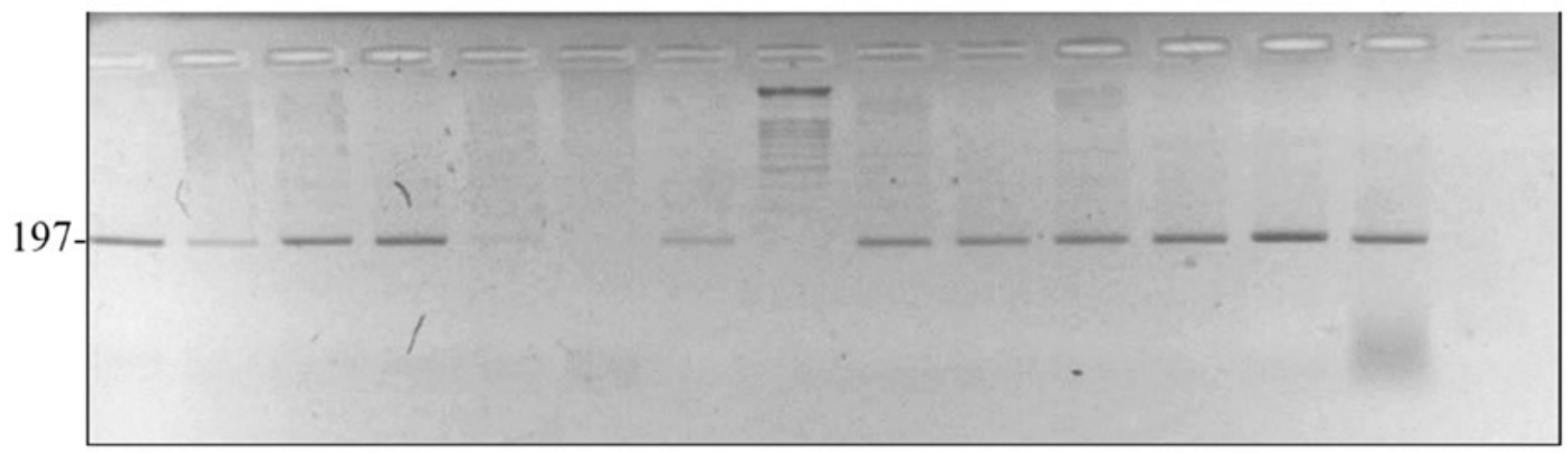

Fig. 3. $\mathrm{PCR}$ analysis of transgenic rape plants using CP4 epsps specific primers: Lanes $1-12$ - test samples; $\mathrm{K}_{1}-$ positive control - Agrobacterium tumefaciens GV3101 colony carrying the pCB135 construct; $\mathrm{K}_{2}$ - negative control non-transgenic $B n 1$ line rapeseed plant DNA; $M$ - molecular weight marker DNA LadderMix. 


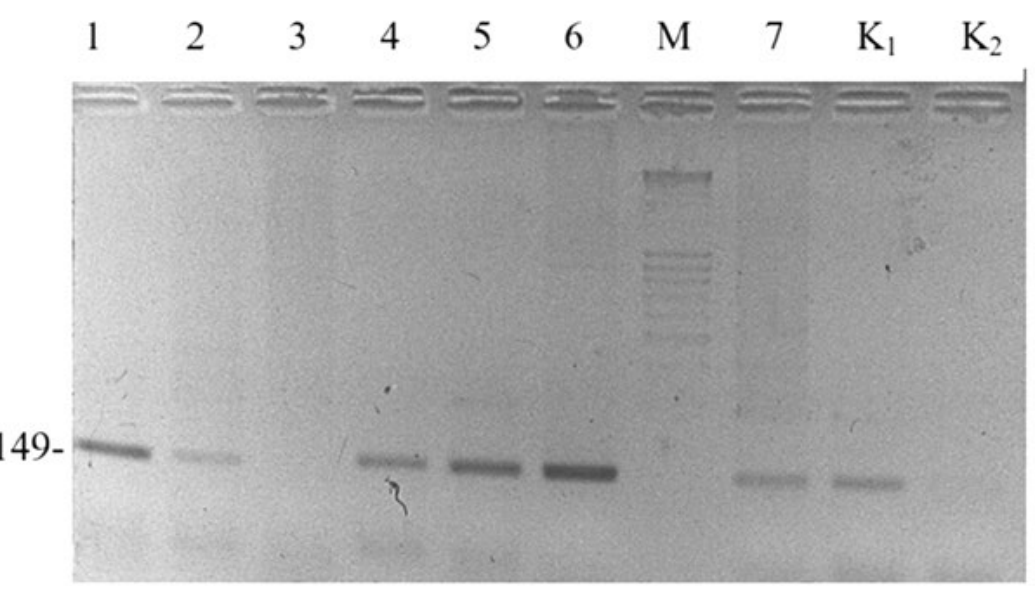

Fig. 4. PCR analysis of transgenic rape plants using CP4 epsps specific primers: Lanes 1-7 - test samples; $\mathrm{K}_{1}$ - positive control - Agrobacterium tumefaciens GV3101 colony carrying the $\mathrm{pCB} 133$ construct; $\mathrm{K}_{2}-$ negative control - non-transgenic $B n 1$ line rapeseed plant DNA; $M$ molecular weight marker DNA LadderMix.

Roundup ${ }^{\circledR}$ (active ingredient - glyphosate, $450 \mathrm{~g} / \mathrm{L}$ ) herbicide treatment was carried out at a rate of $200 \mathrm{~L} / \mathrm{ha}$.

PCR analysis of the CP4 epsps gene confirmed the presence of the transgene in 11 of 12 regenerated rape plants obtained after transformation using the vector pCB135 (Fig. 3).

After PCR analysis of 7 winter oilseed rape lines obtained after genetic transformation using the pCB133 construct, the presence of bar transgene integration was confirmed in 6 regenerated plants (Fig. 4).

The presence of CP4 EPSPS protein in PCR-positive samples of winter oilseed rape was checked using an immunotest system with monoclonal antibodies coated test strips. The appearance of a band on the test system indicates the presence of a specific protein CP4 EPSPS, as shown in Fig. 5. The QuickStix ${ }^{\mathrm{TM}}$ Kit immunoassay system confirmed the results of previous PCR analyses: the presence of CP4 EPSPS protein was detected in 11 winter rape regenerated plants obtained after genetic transformation with the pCB135 construct, and in 6 plants after transformation with the pCB133 genetic construct.
The plants that survived after glyphosate treatment were vernalized in accordance with [18-20]. The obtained seeds did not differ

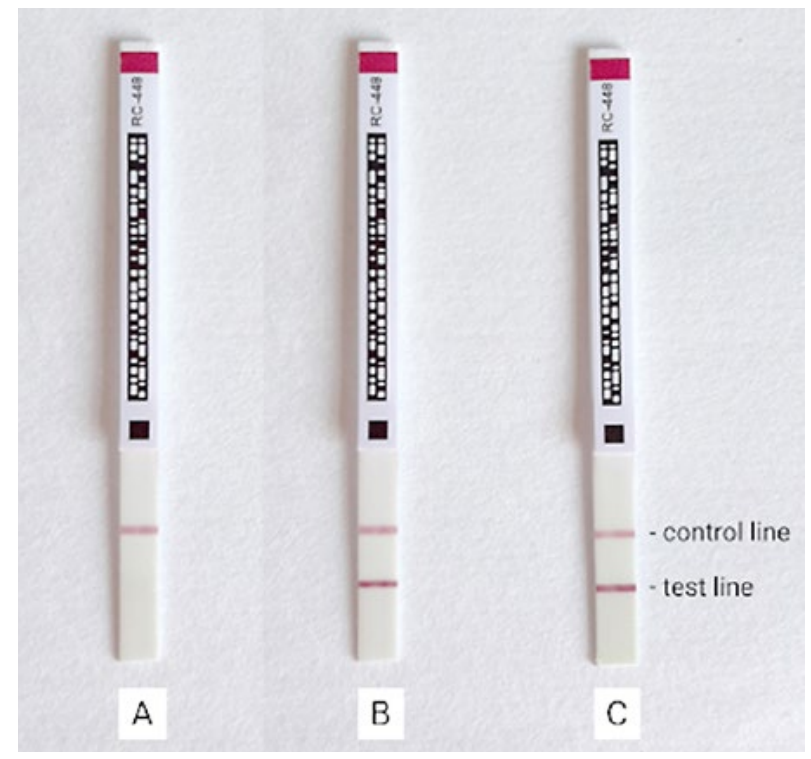

Fig. 5. The CP4 EPSPS protein expression analysis results in rapeseed plants using the QuickStixTM Kit immuno-test system: $A$ - non-transgenic $B n l$ line rapeseed leaf extract; $B$ - CP4 EPSPS expression in rapeseed leaf extract after transformation with the pCB135 construct; $C$ - CP4 EPSPS expression in rapeseed leaf extract after transformation with the $\mathrm{pCB} 133$ construct. 


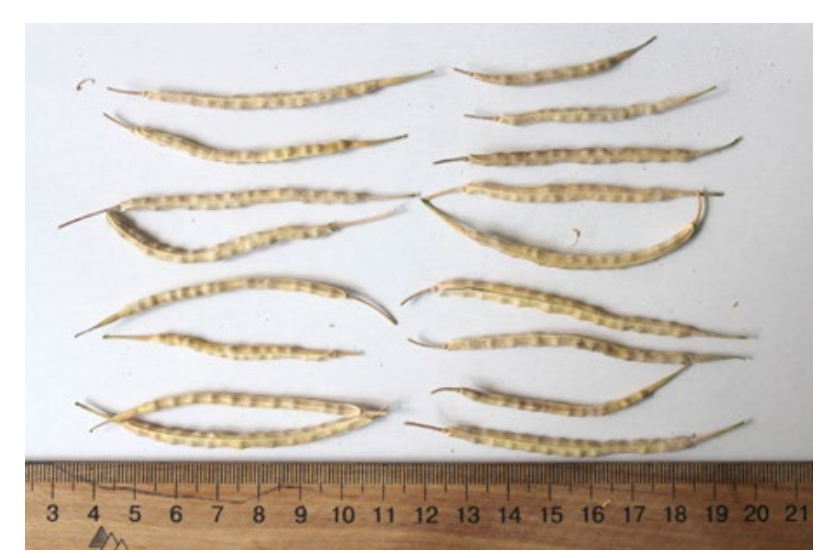

Fig. 6. $T_{0}$ generation seed pods, obtained after transgenic plants of winter rape vernalization

morphologically from non-transgenic ones (Fig. 6).

The obtained seeds were sterile germinated on a MS nutrient medium. The tops of 6-dayold seedlings were sterile cut and planted on MS medium supplemented with a selective agent: $8 \mathrm{mg} / \mathrm{L} \mathrm{ppt} \mathrm{for} \mathrm{lines} \mathrm{carrying} \mathrm{the}$ pCB133 vector and $50 \mathrm{mg} / \mathrm{L} \mathrm{Km}$ for lines carrying $\mathrm{pCB} 135$ vector. One week later, segregation was determined due to the selective agent resistance (Table 2): non-resistant plants turned yellow and died, resistant ones stayed green and formed roots.

In all plants, except the T1Bn/133/8 line, $3: 1$ genetic segregation was observed on the basis of selective antibiotic resistance (Table 2). The Chi-squared test for goodness of fit value for the line $\mathrm{T} 1 \mathrm{Bn} / 133 / 8$ significantly goes beyond the standard $\chi_{\text {st }}^{2}=3.84$, which can be explained by the insufficient amount of seeds or low corresponding transgene expression.

\section{Conclusion}

Thus, as a result of the genetic transformation experiments on the $B n l$ commercial line of winter oilseed rape, 11 biotechnological plants with the glyphosate (epsps) and kanamycin (nptII) resistance genes were obtained, as well as 6 plants carrying phosphinothricin (bar) as well as epsps resistance genes in the nuclear genome. The expression of selective agents resistance genes was confirmed in the $\mathrm{T}_{1}$ plants generation.

\section{Table 2. Genetic analysis of $\mathbf{T}_{\mathbf{0}}$-derived biotechnological plants}

\begin{tabular}{|c|c|c|c|c|c|}
\hline \multirow{2}{*}{ Rapeseed line } & \multirow{2}{*}{ Seed germination in vitro, $\%$} & \multicolumn{2}{|c|}{ Number of seeds, pcs. } & \multirow{2}{*}{ Segregation } & \multirow{2}{*}{$\chi^{2^{*}}$} \\
\hline & & ppt+ & ppt- & & \\
\hline $\mathrm{T}_{1} \mathrm{Bn} / 133 / 3$ & 91 & 65 & 26 & $3: 1$ & 0.16 \\
\hline $\mathrm{T}_{1} \mathrm{Bn} / 133 / 7$ & 98 & 61 & 37 & $3: 1$ & 2.13 \\
\hline $\mathrm{T}_{1} \mathrm{Bn} / 133 / 8$ & 98 & 19 & 30 & - & 40.41 \\
\hline & & $\mathbf{K m}+$ & Km- & & \\
\hline $\mathrm{T}_{1} \mathrm{Bn} / 135 / 1$ & 76 & 61 & 15 & $3: 1$ & 0.28 \\
\hline $\mathrm{T}_{1} \mathrm{Bn} / 135 / 3$ & 90 & 72 & 18 & $3: 1$ & 0.30 \\
\hline $\mathrm{T}_{1} \mathrm{Bn} / 135 / 4$ & 100 & 59 & 41 & $3: 1$ & 3.41 \\
\hline $\mathrm{T}_{1} \mathrm{Bn} / 135 / 6$ & 80 & 48 & 32 & $3: 1$ & 2.40 \\
\hline $\mathrm{T}_{1} \mathrm{Bn} / 135 / 10$ & 90 & 63 & 27 & $3: 1$ & 0.30 \\
\hline $\mathrm{T}_{1} \mathrm{Bn} / 135 / 14$ & 95 & 72 & 23 & $3: 1$ & 0.01 \\
\hline $\mathrm{T}_{1} \mathrm{Bn} / 135 / 20$ & 83 & 56 & 27 & $3: 1$ & 0.63 \\
\hline Bnl (control) & 100 & 0 & 0 & - & - \\
\hline
\end{tabular}

Note. ${ }^{*}-\chi_{\text {st }}^{2}=3.84$ at $\mathrm{P}=0.05$ 


\section{REFERENCES}

1. Gianessi LP. The increasing importance of herbicides in worldwide crop production. Pest Manag Sci. 2013;69(10):1099-105.

2. Imran M, Asad S, Barboza AL, Galeano E, Carrer $H$, Mukhtar Z. Genetically transformed tobacco plants expressing synthetic EPSPS gene confer tolerance against glyphosate herbicide. Physiol Mol Biol Plants. 2017;23(2):453-460.

3. Barry $G$, Kishore $G$, Padgette $S$, Taylor $M$, Kolacz K, Weldon $M$, Re D, Eichholtz D, Fincher $K$, Hallas $L$. Inhibitors of amino acid biosynthesis: strategies for imparting glyphosate tolerance to crop plants. In: Singh BK, Flores HE, Shannon JC (eds) Biosynthesis and molecular regulation of amino acids in plants. American Society of Plant Physiologists. 1992; 7:139-45.

4. Kishore GM, Padgette SR, Fraley RT. History of herbicide-tolerant crops, methods of development and current state of the artemphasis on glyphosate tolerance. Weed Technology. 1992; 6(3):626-34.

5. Zhao Z, Gu W, Cai T, Tagliani L, Hondred D, Bond D, Schroeder S, Rudert M, Pierce D. High throughput genetic transformation mediated by Agrobacterium tumefaciens in maize. Mol Breed. 2001; 8:323-33.

6. Dai S, Zheng P, Marmey P, Zhang S, Tian W, Chen S, Beachy RN, Fauquet C. Comparative analysis of transgenic rice plants obtained by Agrobacteriummediated transformation and particle bombardment. Mol Breed. 2001; 7:25-33.

7. Sakhno LO. Plant biomass increase: recent advances in genetic engineering. Biopolym Cell. 2013; 29(6):443-53.

8. Sakhno LO, Lystvan KV, Kuchuк MV. Antioxidant activity of leaf of biotechnological rape (Brassica napus L.), resistant to herbicides based on glyphosate and glufosinate. Visnyk Kharkivskoho natsionalnoho ahrarnoho un-iversytetu, Seriia: Biolohiia. 2015; 3(36):62-70.

9. Sakhno LO, Komarnitsskii IK, Kuchuk MV. Inheritance of glyphosate and glufosinate resistance in T1-T2 generations of biotechnological canola (Brassica napus L.) plants. Visnyk Ukrainskoho tovarystva henetykiv i selektsioneriv. 2015; 13(1):3-10.

10. Murashige T, Skoog FA. Revised medium for rapid growth and bio assays with tobacco tissue cultures. Physiol Plant. 1962; 15:473-97.

11. Hnatyuk IS, Varchenko OI, Kuchuk MV, Parii MF, Symonenko YuV. Development of an effective in vitro regeneration system for Ukrainian breeding winter rape Brassica napus L. Cytol Genet. 2020; 54(4):341-6.

12. Hnatyuk IS, Varchenko OI, Bannikova MA, Kuchuk MV, Parii MF, Symonenko YuV. Development of an effective technique for in vitro Agrobacteriummediated genetic transformation of winter rape Brassica napus L. AgroLife Scientific Journal. 2020; 9(1):149-55.

13. Bertani $G$. Studies on lysogenesis. I. The mode of phage liberation by lysogenic Escherichia coli. J Bacteriol. 1951; 62(3):293-300.

14. Sambrook J, Fritsch EF, Maniatis T. Molecular Cloning: A Laboratory Manual, 2nd ed. Cold Spring Harbor, NY: Cold Spring Harbor Laboratory. 1989; 1626 p.

15. Mashayekhi M, Shakib AM, Ahmad-Raji M, Ghasemi Bezdi K. Gene transformation potential of commercial canola (Brassica napus L.) cultivars using cotyledon and hypocotyl explants. Afr J Biotechnol. 2008; 7(24):4459-63.

16. Rahnama H, Sheykhhasan M. Transformation and light inducible expression of crylab gene in oilseed rape (Brassica napus L.). J Sci Islamic Repub Iran. 2016; 27(4):313-9.

17. Cardoza V, Stewart CN. Increased Agrobacteriummediated transformation and rooting efficiencies in canola (Brassica napus L.) from hypocotyl segment explants. Plant Cell Rep. 2003;21(6):599-604. doi: 10.1007/s00299-002-0560-y.

18. Savelieva EM, Tarakanov IG. Control of flowering in canola plants with various response to photoperiodic and low-temperature induction. Izvestiya of Timiryazev Agricultural Academy. 2014; 2:57-68.

19. Filek M, Koscielniak J, Macháčková I, Krekule J. Generative development of winter rape (Brassica napus L.) - The role of vernalization. International J Plant Develop Biol. 2007; 1(1):57-63. 
20. Waalen WM, Stavang JA, Olsen JE, Rognli OA. The relationship between vernalization saturation and the main-tenance of freezing tolerance in winter rapeseed. Environ Exp Bot. 2014; 106:164-73.

\section{Створення біотехнологічних рослин комерційної лінії озимого ріпаку Brassica napus L., стійких до дії гліфосату}

I. С. Гнатюк, О. I. Варченко, М. В. Кучук, М. Ф. Парій, Ю. В. Симоненко

Мета. Створити біотехнологічні рослини озимого ріпаку комерційної лінії, які несуть гени резистентності до гліфосату та фосфінострицину. Методи. Використовували метод культури тканин in vitro, метод Agrobacterium-опосередкованої генетичної трансформації, метод полімеразної ланцюгової реакції та метод $\chi^{2}$. Результати. Наведено результати ПЛР аналізу біотехнологічних рослин озимого ріпаку, отриманих після генетичної трансформації, за геном CР4 epsps, який підтвердив наявність вставки у 11 з 12 рослин, а також за геном bar, яким підтверджено наявність інтеграції трансгену у 6 з 7 рослин. Всі отримані рослини-регенеранти були адаптовані до умов in vivo, оброблені гліфосатом та яровизовані. Отримане насіння стерильно пророщували та визначали розщеплення за ознакою стійкості до селективного агента. Висновок. Отримано 11 біотехнологічних рослин 3 генами стійкості до гліфосату (еpsps) та канаміцину (nptII), а також 6 біотехнологічних рослин, що крім гена epsps містять в ядерному геномі гени стійкості до фосфінотрицину (bar). Наявність білка CP4 EPSPS в трансгенних рослинах ріпаку доведена за допомогою молекулярного аналізу експресії білків використовуючи імуно-тест систему. Експресію генів стійкості до селективних агентів було підтверджено у поколінні $\mathrm{T}_{1}$.

К л юч о в і с л ов а: Brassica napus, озимий ріпак, ген bar, ген epsps, ген nptII, генетична трансформація.
Создание биотехнологических растений коммерческой линии озимого рапса Brassica napus L., устойчивых к действию глифосата

И. С. Гнатюк, О. И. Варченко, Н. В. Кучук, М. Ф. Парий, Ю. В. Симоненко

Цель. Создать биотехнологические растения озимого рапса коммерческой линии, которые несут гены резистентности к глифосату и фосфинострицину. Методы. Использовали методы культуры тканей in vitro, метод Agrobacterium-опосредованной генетической трансформации, метод полимеразной цепной реакции и метод $\chi^{2}$. Результаты. Приведены результаты ПЦР анализа биотехнологических растений озимого рапса, полученных после генетической трансформации, по гену CР4 epsps, который подтвердил наличие вставки в 11 из 12 растений, а также по гену bar, которым подтверждено наличие интеграции трансгена у 6 из 7 растений. Все полученные растения-регенеранты были адаптированы к условиям in vivo, обработаны глифосатом и яровизированы. Полученные семена стерильно проращивали и определяли расщепление по признаку устойчивости к селективному агенту. Вывод. Получено 11 биотехнологических растений с генами устойчивости к глифосату (epsps) и канамицину (nptII), а также 6 биотехнологических растений, которые кроме гена epsps содержат в ядерном геноме гены устойчивости к фосфинотрицину (bar). Наличие белка CP4 EPSPS в трансгенных растениях рапса доказано с помощью молекулярного анализа экспрессии белков с использованием иммуно-тест системы. Экспрессию генов устойчивости к селективным агентам было подтверждено в поколении $\mathrm{T}_{1}$.

Кл юч ев ы е сл ов а: Brassica napus, озимый рапс, ген bar, ген epsps, ген nptII, генетическая трансформация.

Received 10.09.2020 